AperTO - Archivio Istituzionale Open Access dell'Università di Torino

\title{
Persistent akinetic mutism after bilateral paramedian thalamic infarction
}

\section{This is the author's manuscript}

Original Citation:

Availability:

This version is available http://hdl.handle.net/2318/1701019

since 2019-05-06T19:42:08Z

Published version:

DOI:10.1176/jnp.2009.21.3.351

Terms of use:

Open Access

Anyone can freely access the full text of works made available as "Open Access". Works made available under a Creative Commons license can be used according to the terms and conditions of said license. Use of all other works requires consent of the right holder (author or publisher) if not exempted from copyright protection by the applicable law. 


\title{
Persistent Akinetic Mutism After Bilateral Paramedian Thalamic Infarction
}

\author{
Andrea Eugenio Cavanna ${ }^{1}$ M.D., Luca Bertero² ${ }^{2}$, Stefano Cavanna ${ }^{2}$, Serena Servo ${ }^{3}$ M.D., Gionata \\ Strigaro $^{3}$ M.D., Francesco Monaco ${ }^{3}$ M.D. \\ 1 Department of Neurology, Amedeo Avogadro University, Novara, Italy; Institute of Neurology, \\ UCL, London \\ 2 University of Turin Medical School, Turin, Italy \\ 3 Department of Neurology, Amedeo Avogadro University, Novara, Italy
}

To the Editor: Akinetic mutism is a pathological condition characterized by lack of spontaneous movements with little or no vocalization in subjects with intact corticospinal pathways. ${ }^{1}$ This condition was first described in patients who suffered diencephalic damage, and current evidence indicates that it is a transient state resulting from lesions that interfere with reticular/cortical integration. ${ }^{2}$ We present a rare case of persistent akinetic mutism after bilateral paramedian thalamic infarction.

\section{Case Report}

S.I., an 81-year-old man without any significant previous medical history, was admitted to the Department of Neurology at Amedeo Avogadro University in Novara, Italy, after the acute onset of bilateral thalamic infarct. On admission he presented with a sleep-like state, respiratory failure, unresponsiveness, and double incontinence. While he was physically and emotionally active before stroke, he became apathetic, aspontaneous, indifferent, and seemed to have lost motor and affective drive, as well as the need itself for any psychic activity. A brain CT and MRI, performed on admission and during the following week, showed bilateral ring-shaped signal alterations in the paramedian thalamic regions with the right one being characterized by major dimension. The signal hyperintensity in long TR sequences and the hypointensity in T1 sequences were consistent with right paramedian artery territory infarction and contralateral territory involvement, which presumably led to ischemic lesions of paramedian and intralaminar nuclei. Electroencephalographic recordings demonstrated diffuse cortical slowing associated with epileptiform discharges. During hospitalization, the patient showed no sign of recovery, with the exception of normal sleep-waking cycle. At 6-month and 1-year follow-up visits he still met Cairns' criteria for akinetic mutism.

\section{Discussion}

Bilateral thalamic infarcts are uncommon, as they represent about $0.6 \%$ of first ever acute stroke. ${ }^{3}$ The most common clinical picture associated with bilateral paramedian thalamic artery infarction includes coma, loss of consciousness or somnolence at stroke onset, followed by transient concentration and orientation deficits, and memory dysfunctions (thalamic dementia). More rarely, small bilateral thalamic lesions can also lead to the clinical pictures of akinetic mutism (failure to respond to relevant stimuli) and athymhormia ("loss of psychic self-activation”). ${ }^{2-4}$

Akinetic mutism is usually a transient condition, whereas with both thalamic dementia and athymhormia there is less of a chance of recovery. In our patient, the damage extended from the paramedian to intralaminar nuclei, possibly leading to permanent disruption of higher-level thalamocortical integration pathways controlling consciousness, without affecting the core of 
pontine tegmentum, whose damage is selectively associated with coma. ${ }^{5}$ On the other hand, the circuitry from intralaminar thalamic nuclei to the prefrontal cortex and back to the nucleus reticularis has been suggested to serve as a gate control, selectively preparing the aroused organism for responses to meaningful stimuli. ${ }^{6}$

\section{Bibliography}

1. Cairns H, Oldfield RC, Pennybacher JB, et al: Akinetic mutism with an epidermoid cyst of the third ventricle. Brain 1941; 64:273-290

2. van Domburg PH, ten Donkelaar HJ, Notermans SL: Akinetic mutism with bithalamic infarction: neurophysiological correlates. J Neurol Sci 1996; 139:58-65

3. Kumral E, Evyapan D, Balkir K, et al: Bilateral thalamic infarction. Acta Neurol Scand 2001; 103:35-42

4. Engelborghs S, Marien P, Pickut BA, et al: Loss of psychic self-activation after paramedian bithalamic infarction. Stroke 2000; 31:1762-1765

5. Parvizi J, Damasio A: Neuroanatomical correlates of brainstem coma. Brain 2003; 126:15241536

6. Crick F: Function of the thalamic reticular complex: the search light hypothesis. Proc Natl Acad Sci U S A 1984; 81:4586-4590 